IRSH 48 (2003), pp. 427-455 DOI: I0.I0I7/So02085900300I I 47

(C) 2003 Internationaal Instituut voor Sociale Geschiedenis

\title{
The Brickworkers of Khatunabad: A Striking Record (1953-I979)
}

\author{
WILLEM FLOOR
}

Summary: This article discusses the working and living conditions of unskilled labourers in South Tehran, and pays particular attention to the workers of the brickkiln factories of Khatunabad. The brick-kiln workers, mostly transient rural workers, were among the poorest of the Iranian labour class. At the same time, in terms of sheer numbers they represented s per cent of the population of Tehran in I960. They lived and worked under appalling conditions but, nevertheless, they only seldom went on strike. The brickworkers' main concern was not so much their working conditions, but rather to get and hold a job. This was difficult, because (I) they were seasonal labour; (2) they had no representative workers' organization to speak for them; (3) the way their industry was organized left them with little power; and (4) there was strong competition from other unskilled and unemployed labourers. Finally, the six known strikes by the brick-kiln workers will be highlighted, and used to discuss the context in which all Iranian workers had to operate.

\section{INTRODUCTION}

Studies on the labour class in Iran are very limited in number and indicate a glaring absence of interest in the subject. The few studies that are available focus on labour in modern industry and invariably ignore the much larger numbers of unskilled labour. Also, they are limited as far as the historical period is concerned, and there is no study covering the period I95I-I979. ${ }^{\mathrm{I}}$ Ironically, the content and nature of many pamphlets published by leftist organizations between 1979 and $198 \mathrm{I}$, including articles in their newspapers, underline this continued neglect of the labour class. These articles were mostly of a highly theoretical and doctrinal nature, and one might read them without ever learning anything about the labour class in Iran.

I. The main studies are A. Bashkirov, Rabochee i profsoinznoe dvizhnie v Irane (Moscow, 1948); S.M. Badi, Rabochii Klass v Irane (Moscow, I965); Z.Z. Abdullaev, Promyshlennost' $i$ zarozhdenie rabochego klassa Irana v kontse IXI-nachale XX vv (Baku, I963); Habib Ladjevardi, Labor Unions and Autocracy in Iran (Syracuse, NY, 1985); and Willem Floor, "Labour Unions, Law and Conditions in Iran (1900-194I)", Occasional Paper no. 26, Durham University, 1985 . 
This is one reason why I opted to discuss the working and living conditions of the brickworkers of Tehran between 1953-1979, but also because they were among the poorest and the most ignored of Iran's urban workers.

Unemployment and lack of skills have been a structural problem for the labour force in Iran. Data on involuntary unemployment before 1940 are lacking, but in general it was likely to be low. Data on unemployment after I950 suggest climbing unemployment rates due to fast-growing urbanization, stagnation in the building industry, factory closures due to foreign competition, lagging development, and rural exodus. Unemployment rates became double-digit after I955. At the same time, the size of the urban labour class nevertheless grew in both absolute and relative terms. The total number of workers in the industrial sector increased from 7 per cent in 1910 to 24 per cent in 1956 and to 30 per cent in $1978 .^{2}$

Despite their large number in Tehran, the brickworkers were not even included in the official government statistics. The latter were rather deficient in general. It is only in recent times that data have become available on the actual size of the urban labour force, and even then these data were not disaggregated - thereby preventing one from identifying the number of brick-kiln workers for example. The early data from 1956 and 1963 are incomplete, and they do not distinguish between modern industry and traditional crafts. The casual labour force in summer was estimated at some 50,000 men in 1955, a number that increased to I 50,000 during winter. However, this number was actually 300,000 in winter due to rural migrants. ${ }^{3}$ In 1960, the brick-making industry employed 2 I,000 people, thus indicating unemployment of 29,000 workers, assuming that most casual labour were brickworkers. In that year, the number of jobs in the construction industry decreased by 72,500 , so total unemployment in that sub-sector would have been I0I,500. At that time, total underemployment was estimated at 40 per cent of the urban labour force. ${ }^{4}$ The great majority of the labour force was illiterate. In 1956, according to the census, 84 per cent of the population above the age of Io was illiterate. Much was done to invest in education to reduce this number, but 60 per cent of the employed population was still illiterate by 1986.5

2. Julian Bharier, Economic Development in Iran 1900-1970 (London, 1971), pp. 35-36; Echo of Iran, Iran Almanac 1963 (Tehran, I964), p. 405; ILO, Employment and Income Policies for Iran (Geneva, I973), pp. 26-29.

3. UK Government, "Workers' Lot in the Post-Coup d'État Era", in Cosroe Chaqueri (ed.), The Condition of the Working Class in Iran: A Documentary History I9I I-1979, vol. 4 (Tehran, I99I), p. 82; US Government, "Basic Survey of Labor Affairs in Iran", in ibid., p. 88.

4. US Government, "Annual Labor Report 1961", in ibid., p. 172.

5. Hooshang Amirahmadi, Revolution and Economic Transition: The Iranian Experience (Albany, NY, I990), p. I89. 
The main problem for the workers was, firstly, to get a job and keep it, and, secondly, to make a living with the low wages that they earned. As a result of these two problems, workers became mired in a vicious circle of low wages, malnutrition, poor housing and poor health, illiteracy, lack of skills, and low productivity, resulting in a continuation of low wages. The problems of the brickworkers had an extra dimension. They were mainly rural seasonal migrant labour. A considerable part of the rural population, which represented about 60 per cent of the total population by 1970, existed at the subsistence level. Part of the year, peasants were idle and migrated to the towns to look for work to increase their low incomes. Here, they had to compete for the few jobs open to unskilled labour with many unskilled labourers, who formed a structural part of the urban labour force. This had, of course, a negative impact on the level of wages as well as on the employment ratio. Moreover, this influx of transient rural labour during the winter period coincided with a reduction in activity in the construction industry, in particular in brick-making, which employed a large number of unskilled and semiskilled labourers. As a result, most brickworkers earned just enough to get by, and, as a consequence, their diet, health, and housing were poor. ${ }^{6}$

\section{WHO WERE THE BRICKWORKERS?}

Our discussion about the brickworkers will focus on those that worked at the Khatunabad kilns - which were the largest concentration of kilns around Tehran. It would therefore be useful to provide some background information on the old village of Khatunabad, before its fertile fields were turned into bricks.

In the nineteenth century, Khatunabad was the first village at which all travellers stopped on their way from Tehran to Khorasan. Khatunabad was situated 28 kilometres from Tehran's Mashad gate. In i 85 I, 80 per cent of the village land consisted of crown-land property (khaleseb) and 20 per cent was property owned by absent landlords (arbabi). The farmers cultivated much rice. In I 876, Khatunabad was still a crown-land village, and boasted eighty families, one large caravanserai with forty rooms, and large stables built by Hajji Molla Ali. It was also still a thriving agricultural community but, despite the abundance of crops, the villagers sold food and fodder at high prices to passers-by. If the officials that passed through failed to produce the proper documentation, these villagers even begrudged them the gratis supplies or purveyance (soyursat) to which

6. US Government, "Basic Survey", in Chaqueri, Condition, pp. 87-88; UK Government, "Labour and Social Affairs 1956", in ibid., p. Ior; ILO, Problems of Employment Creation in Iran (Geneva, 1970); Bharier, Economic Development, pp. I39-I4I. 
they were entitled.7 The good soils and location that made Khatunabad one of the food suppliers for Tehran in the Qajar period (I797-1925) also made it an excellent candidate to supply Tehran with its building materials in the twentieth century.

In the I960s and I970s, most of the brick-kiln workers in Khatunabad originated from villages in Khorasan, in particular from the "Turkish"speaking area of Quchan and the Persian-speaking Torbat-e Heidari and Torbat-e Jam areas. The Persian-speaking groups were referred to as Khorasanis. The latter were said to represent 45 per cent of the labour force in I970, according to Taheri. The rest were "Turks" from Quchan, from villages around Hamadan, and Persian speakers from Zabol, who had moved to Gorgan, where they had also been employed in brick kilns. Despite the varied origins of the workers they generally had no major problems working together, despite the fact that the owners tried to set Khorasanis against "Turkish" speakers and/or Zabolis. "Turkish” speakers from Quchan were called qamir (kiln [worker]) or Turkha-ye Siyadu'i. According to the nonscientific, and therefore unrepresentative, sample studied by Taheri in 1970, the average age of the brick-kiln workers was twenty-seven. Only ten were over forty, and the maximum age was fifty. At least half the workers were married, and had on average three children. About 90 per cent were illiterate, and very few were able to read and write fluently. ${ }^{8}$

Most workers did not have land of their own. They had received some land as a result of the land reform programme, but in the absence of water they were unable to valorize their property and they needed to make money in the agricultural off-season to make ends meet. A contractor (ostadkar-e zir), who had a contractual relationship with the kiln owners, hired these landless workers. The position of ostadkar-e zir was one that all brickworkers aspired to. Zir is a Khorasani kiln term meaning "the chief in charge of the production unit". The ostadkar had the right to Io per cent of the workers' salary for his trouble, which included his expenses for travelling to the villages, getting the work crews together, and paying them an advance. Payment was usually in three instalments; (I) on signing up, (2) at the start of the job, and (3) at the end of the contract. The contractor could use the workers for any kind of work. To keep them in his "stable" he tried to bind them to him by various means, especially by securing advantages for them and getting them into his debt. For example, bachelors

7. Mirza Ebrahim, Safarnameh-ye Astarabad va Mazandaran va Gilan, Mas'ud Golriz (ed.) (Tehran, I976), p. 4; Qodratollah Roushani Za'franlu (ed.), Seh Safarnameb (Herat, Merv, Mashad) (Tehran, 1977), pp. 3, I48. For the terms khaleseh, arbabi, and soyursat, see Willem Floor, The Fiscal History of Iran in the Safavid and Qajar Periods (New York, 1999).

8. Anonymous, Qiyam-e Kargaran-e Kheshtmal (Tehran, n.d.) [Az seri-ye gozareshat-e kargari marbut beh burzhvazi-ye melli Nr. I, Nabord baraye reha'i-ye kargar], pp. 2, 5, 6, note; Reza Taheri, "Negahi beh kurehpaz-khaneh", Ketab-e Hafteh, I (19) (1979), pp. I07-108. 
would have their food cooked and clothes washed by the family of the sarkargar or foreman. The sarkargar was one of the workers who, generally speaking, represented their interests. He obtained things for them: gloves, shoes, etc. He also called strikes, although usually only after having been pressured by the workers to do so. ${ }^{9}$

Not only adults (both men and women) were employed; quite a few children joined their parents on the seasonal migration too and also worked in the kilns. There was even a transfer of know-how from father to son; sometimes, three generations were working in the same kiln. Those employed as assistant moulders (qalebkesh) were mostly children of the moulders (kheshtmals); the wives of the moulders were often employed as brick stackers (kbesht jam'kon). The Khorasani worker's wife was therefore an important asset, as were those children aged twelve to seventeen. As a result, many workers often literally worked like a family, and even if they were not from the same family they often were from the same village. In this way there was also peer and family pressure to work, even if you were sick, so as not to let the production team - or rather the family - down. In addition to working as brick stackers (khesht jam 'kon), the Khorasani women also took care of the children, baked bread, washed clothes, etc. The mother's wages depended on the child's age and varied from 2,000 to 7,000 tomans for seven months' work in 1978 . To discourage the children from running away, about half of the sum contracted for was not paid by the contractor until the end of the contract. In fact, adult workers often did not get their wages on a daily or weekly, or even on a monthly, basis. Usually the contractor would pay them enough at the end of the week to cover their daily expenses, but he withheld part of their wages. ${ }^{1 \circ}$ Day workers had to pay a kickback to the contractor or ostadkar, the rate for which was 40 riyals in $1955 .{ }^{.1}$

The workers might be employed in the following jobs: as a fireman (kurebsuz), kiln loader (kurebchin), brick remover (qermez darar), moulder (kheshtmal), stacker of baked bricks (anbarzan), winch operator (charkbkesh), fuel man (sukhtkesh), digger (kelengdar), mixer (gelsaz), assistant moulder (qalebkesh), or brick stacker (khesht jam 'kon). Some of these jobs required more skill than others, in part because a greater risk was involved. Consequently, those jobs that required a higher level of skill were paid more, and whereas unskilled workers were hired only as casual labour on a seasonal basis, these skilled workers were offered a contract for a year or more (see Table I overleaf). ${ }^{22}$ The pay-scale was not only a

9. Anonymous, Gozareshi dar bareh-ye kurehpazkhanehha-ye Khatunabad (SiyavoshanResht, n.d. [1980]), pp. 3-4; Anonymous, Qiyam-e Kargaran, pp. I I-I4.

ı. Anonymous, Gozareshi, p. 5; Taheri, "Negahi”, p. ı०7; Anonymous, Qiyam-e Kargaran, pp.

I4-I 5, I 7 .

I I. US Government, "Basic Survey", p. 88; ro riyals was equivalent to I toman.

I2. Taheri, "Negahi", pp. 98-99. 
Table I. Skill levels and employment duration among brickworkers

\begin{tabular}{ll}
\hline Skill level by type of job & Kheshtmal, kurebchin, kurehsuz, qermez darar \\
Skilled & Qalebkesh, anbarzan, sukbtkesh \\
Semiskilled & Kelengdar, gelsaz, charkhkesh, khesht jam'kon \\
Unskilled & Kurehchin, kurehsuz, qermez darar, charkhkesh \\
Employment duration by type of function \\
Year-round & Kelengdar, gelsaz, kheshtmal, qalebkesh, khesht \\
Six months only & jam'kon, \\
(spring to winter) & Anbarzan \\
Seven months & \\
(April to November) &
\end{tabular}

Source: Taheri, "Negahi”, p. 99.

reflection of differences in skill, but also in risk. The highest paid, after the kiln loader (kurehchin), was the winch operator (charkbkesh), because his job was considered to be dangerous. The kiln loader (kurehchin) earned about I,000 tomans, and the winch operator (charkhkesh) 800 tomans per week in the mid-I970s. The coal hauler (dhoghalkesh) earned 500 tomans per week, while the fireman (kurebsuz), brick remover (ajordarbeyar), and the assistant winch operator (komak-e charkbkesh) received less. Unskilled workers were not paid weekly, but on a piecerate basis (kontrati in the workers' slang), i.e. per output of $\mathrm{I}, 000$ bricks. ${ }^{\mathrm{I}}$

The raw bricks that the workers made were stored during the spring and summer and sold in the year or years thereafter. Workers felt cheated because (certainly in nominal terms) the owners received more for these bricks than they would have done in the past, due to inflation. Because the bricks were stored by the owners, the latter used the physical presence of the bricks as a means to put pressure on workers: the message, clearly, was that the owners hardly needed workers at all, and certainly not at those "high wages", since they still had so many unsold bricks. All kinds of abuses crept in, such as wages not being paid daily - otherwise the owners would have had to pay for each day's production, including both good and bad bricks. Now they paid per batch, and then only for good bricks. Workers often worked sixteen-hour days, although officially the working day was only eight hours. Nor did they benefit from profit-sharing and social-security schemes. ${ }^{\mathrm{I}}{ }^{4}$

The brick-making season began on Noruz (New Year's Day, or $2 \mathrm{I}$ March) and lasted six or seven months, depending on the type of work (see

I3. Ibid., p. 98; Anonymous, Qiyam-e Kargaran, pp. 9-ı.

I4. Anonymous, Gozareshi, pp. 5-6; Anonymous, Qiyam-e Kargaran, pp. 8, I4. Social security and profit-sharing schemes had been instituted in 1953 (amended in 1969) and 1973 respectively. 
Table I). After that, the "Turkish" lime workers, for example, returned to their families. ${ }^{\text {Is }}$ In March, the contractors brought their workers to the kilns. Here they would stay until the beginning of November. Because they had no land themselves and were without agricultural work for five months of the year, they needed the income to make ends meet. Therefore, they often had to borrow money. One source of funds was the contractor (ostadkar), who advanced them money. Often, this money was made available from an advance made by the kiln owners to the contractors, who lent it on to the workers. In this way the workers were entirely dependent on the contractors. This was also to the advantage to the kiln owners, who tried to avoid employing workers directly. In this way they could circumvent the various labour and social security laws, which only applied to those industrial establishments that employed more than ten workers. ${ }^{16}$

In the factory, the kiln owner was usually represented by an agent, known as sar-'amaleh. This agent was either a "Turkish"-speaker or a Khorasani, and had come up through the ranks. An aspiring agent would usually have been a foreman (sarkargar), and then a kiln loader (kurebchin). They were selected because of their loyalty to the kiln owner (arbab). The agents usually lived in the same conditions as the workers. Their tasks were to make sure all the materials necessary to make the bricks were available, to hire and fire workers, and to lower or raise wages. There were usually four of them per kiln, and they were usually from the same region as the workers. ${ }^{17}$ Because of this system, the workers had no direct contact with the kiln owners. All the problems that workers raised were blamed by the contractor on the owners, while he blamed the workers for the demands imposed on him by the owners. The contractor kept part of the workers' wages for himself, as a fee for reserving jobs for "his workers" for the next season.

\section{WORKING ORGANIZATION AND CONDITIONS}

Traditionally, the brick kilns had always been located in the south of Tehran. A European established the first modern brick kiln there around I $905 .{ }^{18}$ However, it was not until 1935 that a German engineer constructed

I5. Anonymous, Qiyam-e Kargaran, pp. 3, 8.

16. Anonymous, Gozareshi, pp. 3-4.

17. Anonymous, Qiyam-e Kargaran, p. Iо.

I8. Willem Floor, "The Ceramics Craft in Qajar Iran", in idem, Traditional Crafts in Qajar Iran, I800-1925 (Costa Mesa, 2003). For pictures of brick-making in South Tehran at the beginning of the twentieth century see Sir Percy Sykes, "Persia: I. Pastoral Life in the Land of the Shah and Its Past Grandeur and Present Predicament", in J.A. Hammerton (ed.), Peoples of all Nations, vol. 6 (London, 1922), pp. 40I2-40I4, which shows that the methods used by this craft in the 1950s and I960s had not changed much. 
a modern type of brick kiln with the typical high chimney in South Tehran. It was based on a design by Friedrich Hoffmann (I 8 I 8-I 890). This type of kiln was therefore known as a hofman in the industry, and it dominated the skyline of the kiln area, which appeared like a forest of chimneys. At the end of the I940s, the traditional brick-kiln owners were told to move out to Hashemabad because they were within the city limits. In subsequent negotiations it was agreed that the move would be made over a period of six years. Before those six years had elapsed the kilns had to have gone; because many had not, they were moved by force to Farahabad. The modern kilns gradually ousted the traditional Iranian kilns. ${ }^{19}$ By their very nature, the brick kilns moved south and east anyway, because when the holes in the ground had become too deep the kilns were moved farther away, and the process started all over again. The abandoned kiln pits were taken over by the poor (see the section on housing below). ${ }^{20}$ According to data from the municipality of Tehran, by 1969 there were 217 kilns around Tehran, distributed over 7 zones, in addition to 9 modern machine kilns. But these figures were not up to date; at that time, many kilns at Esma'ilabad for example were idle. Even the Ministry of Labour did not have reliable data. ${ }^{21}$ By the 1970s, the brick kilns around Tehran were located in the Qarchak-Veramin district, Shamsabad (I $2 \mathrm{kms}$ along the Saveh road), Esma'ilabad (4 kms along the Saveh road), Mahmudabad (Is $\mathrm{kms}$ along the Khorasan road), and at Khatunabad (20 kms along the Khorasan road), which, with 35 to 40 kilns, was the most important location. ${ }^{22}$

On average, each investor owned two kilns; the range was one to four. Basically the kilns, of which there were two kinds, were long tunnels, divided into twelve or twenty-four sections or qamir, with thick walls four metres high. Each section could hold 25,000 to 28,000 bricks. An opening about one-and-a-half times the height and three times the width of a person separated these sections from one another. Each kiln tunnel had either twelve or twenty-four of these openings (dargab), depending on the number of sections (qamir). Each qamir could be accessed from the roof through thirty holes (daricheb). After the unfired bricks had been stacked in the kiln, these openings were closed with mud and the kiln was then fired. The smoke was evacuated through a chimney (manar), called mil by the workers. Usually, all the members of the individual production units

19. Keyban (6 Tir 1336/26 June 1957), p. 7.

20. X. de Planhol, "Recherches sur la géographie humaine de l'Iran septentrional", Mémoires et Documents, 9, fasc. 4 (1964), p. 67 (for pictures of the forest of chimneys and an abandoned kiln pit see plate is).

21. Taheri, "Negahi", p. 94.

22. Anonymous, Qiyam-e Kargaran, p. 19; Anonymous, Gozareshi, p. 3. In 1959 there were some 170 brick kilns in operation. By 1979 the complex at Khatunabad had some 45 kilns. 
belonged to one and the same family. The twelve-section kilns were operated by a group of seven people, comprising:

One person to stack the bricks inside the kiln (kurehchin), two responsible for firing the kiln (kurebsuz), four to carry the fired bricks out of the kiln (ajordarbeyar), one of whom supervised the entire group. In a 24-section kiln, there were two groups of seven, generally called ateshkar. Each production unit or dastgah made 5,000 to 8,000 bricks per day. ${ }^{23}$

In every kiln there was a supervisor (sar-'amaleb). His main function was to count the number of bricks made and to check how the work was being carried out. He generally did not accept the workers' count, only his own; this, workers claimed, usually favoured the owners. The supervisors were believed to make between 3,000 and 4,000 tomans per month, and they lived in quarters separate from the workers. ${ }^{24}$

The kiln area consisted of three sections: the kiln, the field, and the workers' living quarters. The kiln (kureb) and its sections (qamir), were situated at the bottom of the factory's area. On top of the kiln there were dwellings for the kiln workers (i.e. the qamir Turks). There is some difference of opinion among the available sources as to how many workers were needed to operate one kiln. For each qamir the following workers were needed: four kiln loaders (kurehchin), four firemen (kurebsuz), twelve winch operators (charkhkesh), two coal haulers (dhoghalkesh) with two helpers, and one muleteer. Depending on its capacity, each kiln employed ten to twenty work gangs (dastgab), and each work gang consisted of one mixer (gelsaz), one moulder (qalebdar), two assistant moulders (qalebkesh), and two raw brick collectors (khesht jam 'kon).

The field (meidan) was where the raw material was put in a large heap, where the bricks were put into moulds and stacked, and where, later, after they had been returned from the kiln, the fired bricks were warehoused. The field was usually situated higher than the kiln, which made the work of the winch operators easier. The field was the workplace of the production teams (dastgab) of unskilled labourers, of which there were usually two per field. Each production team consisted of one qalebdar, one or two qalebkesh, and one khesht jam'kon. The weekly output per production team was 35,000 to 40,000 bricks, or as many as 45,000 to 60,000 bricks per week if it had two qalebkesh. The raw bricks were either lowered by winch into the kiln or stocked in the field for the winter production. Because the 24-qamiri kilns were operated continuously, each 24-qamiri kiln needed about 30 production teams, which represented about $\mathrm{I} 40$ persons.

23. Anonymous, Gozareshi, p. 3; Anonymous, Qiyam-e Kargaran, pp. 2-3, I5; Taheri, "Negahi", p. 96.

24. Anonymous, Gozareshi, p. 6. 
Finally, there were the workers' living quarters, which were constructed close to the kiln. The "Turks" lived there communally, and the two assistant winch operators (komak-e charkbkesh) usually prepared their food. ${ }^{25}$

Brick making involved the following stages: (I) clay making; (2) brick moulding; (3) mould pulling; (4) collecting raw bricks; (5) carting and arranging the bricks inside the kiln; (6) firing the kiln; (7) removing the bricks; and (8) storing the bricks.

On the field (meidan) the raw material from which the bricks were made was stocked in the forms of heaps (keppeb). If the earth had clods (alu'ak) in it then it was milled. If the clouded earth, in the form of stones, was not milled then kiln ashes were added. The clay (gelsazi) was prepared using a shovel and picks, with the clay that had been bulldozed onto a heap (sormeb in the slang of the workers). The earth was mixed with water, in the same way that cement is made. Workers used both shovels and their bare feet to make the clay plastic and thus ready for use. Most clay makers (gelsaz or kelengdar) developed some kind of rheumatism after a while, and their hands and feet had a cracked skin. This made working painful, and, at times, even impossible.

The next step was qalebdari, or moulding. The qalebdar would take the clay in his hands and put it in a square or rectangular wooden mould, which held four to five brick forms. They worked in competition with other groups and therefore had to work twelve to thirteen hours to ensure that they did not fall behind in production. If the quality of the bricks was unacceptable, the qalebdar was laid off.

The third step was to remove the bricks from the mould, which was done by the qalebkesh. They collected the moulds and therefore had to coordinate their work rhythm with that of the brick-mould makers so that they did not fall behind. This work was usually done by children aged eleven to sixteen. They had to be fast to keep up with the brick moulders. Because of the heavy work, some of the children ran away.

The fourth step was the collection of the raw bricks by the so-called khesht jam 'kon. All these workers were women from Khorasan (the "Turks" and the Zabolis did not bring their wives to the kiln), or their children. They carried the bricks, which had been spread out on the ground, to the field (meidan) next to the kiln. The bricks were stacked cross-wise (kalileb in the slang of the workers) on the field. These women used their bare feet and worked very hard, because the more bricks they collected the more money they made. Those who had children took them to work and let them play there. Babies were breastfed. Where women had 
young daughters, seven or eight years of age, these would help their mothers.

The fifth step was for a worker to winch down (charkbkeshi) the stacked bricks into the kiln, where the brick loader (kurebchin) would take over and stack the bricks inside the kiln. The sides of the kiln would be covered with paper (shabil). Then the kiln opening was sealed using bricks. This was covered with straw-mud (kahgel), and bricks were temporarily put in front of the wall until the shabil had been lit, after which the bricks could easily be removed.

The following step was to fire the kiln; this was done by the kurebsuz or fireman. To light the kiln they used a so-called paper-stick (mileb'i-ye shabil). After the kiln had been sealed off the stokers would feed the kiln regularly with fuel - a mixture of charcoal, fuel oil (roughan-e siyab), sawdust, and steam coal. The stoking was done with small shovels through special openings (daricheb) in the kiln. Those who fired the kiln, as well as all those who worked in the kiln (kurebchiba), and those who mixed the fuel were referred to ateshkarha or stokers. The work of the stokers was unhealthy, and affected both their eyes and lungs.

After the kiln had cooled off the seventh step began, i.e. removing the fired bricks from the kiln. This was done by workers called ajordarbeyar, qermezchi, or qermez darar, i.e. hell's doorkeepers. In the past the bricks were taken out by hand, but in the I970s part of this work was mechanized by using a conveyer belt to load the trucks. Here too, the workers were referred to as charkbkesh. Four or five workers did this work, inside the still hot kiln. Sometimes, they passed out because of the heat and had to be taken outside the kiln, into the fresh air, to recover. It was believed, according to Taheri, that the qermez darar lived shorter than the other workers. The job of the charkbkesh was dangerous, since inattention could result in death or injuries caused by the fast-turning wheel and its handle.

The final stage of the process involved stacking the bricks (anbarzani). These workers, most of whom were Turkic speakers, stacked the bricks at about twenty metres from the kiln and sealed them with straw-mud (kahgel) to keep them for the winter months, when no new bricks were being made. In this manner hand-pressed bricks (ajor-e feshari) were made. ${ }^{26}$

In addition to making clay bricks the kilns also produced various qualities of lime bricks, which were used to provide a white interior or exterior for people's homes. The following products were made: (I) ajor-e babmani: first the earth was milled; then, after the clay had been prepared, the workers levelled it, poured it into moulds and later removed the bricks;

26. Anonymous, Gozareshi, pp. 8-15; Taheri, "Negahi”, pp. 95-96, 99, 107; Anonymous, Qiyam-e Kargaran, p. 9. 
(2) qazaqi-ye safid, which was prepared like ajor-e babmani, the only difference being that no brick dust was added; these bricks are almost white and are used for outside walls; (3) ajor-e farnaz was prepared in the same way; it is a finer quality brick, and only three centimetres thick. This type of brick is mostly for inside use, and is more expensive; and (4) babnaz, which is like babmani, the only difference being the colour babnaz is a simple red, while babmani is spotted red (qermez-e khaldar). ${ }^{27}$

The work in the brick kilns was very hard, unhealthy, and people quickly aged. The workers were always happy to show their hands and feet, which were disfigured due to the water, sand, and heavy labour they had been exposed to, and to bring this point home to those willing or unwilling to listen. In their own words, "kar-e kurehpaz zur ast" [kiln work is hard]. ${ }^{28}$

\section{HOUSING}

Many of the brickworkers, as well as those competing for their jobs, lived in the so-called godals, or depressions, which started south of Shush Avenue. These godals all had individual names, such as 'Arab and $\mathrm{Ma}$ 'sumi. They are excavated pieces of land ranging from 2,000 to 4,000 square metres, and are situated a few metres below the normal street level. The earth excavated had been used to make bricks in the kilns. After the kilns moved on to new pieces of land, these excavated areas were neither restored nor filled up. The owners sold these sites, so that they could be used as housing for poor people. To get to the living quarters in the godals you had to walk down some twenty to thirty steps from street level. Houses built in these depressions were usually 40 to 50 square metres, and very occasionally roo square metres. Rooms of 3 by 4 metres or smaller were built without regard for natural light, etc., and then rented out to poor families. There were usually 6 to Io and sometimes I 2 families living in each of these dwellings. The rent was about 30 to 40 tomans per month in 1963 .

Water, sewage and sanitation posed a problem. At the middle of the complex there was a well, I.5 by I.5 metres, as well as a pond (bouz), which was filled from the well. There was one toilet per dwelling. Sewage water was taken out into the street in a pail and emptied there. Some people bought water from those who peddled it around the dwellings. To wash clothes, rugs, etc., people went to the public taps out in the streets. In some depressions, wells had been dug to drain water from the winter rains. In the depressions there were a few grocery stores, one or two butchers' shops, a bakery, a barber, a shoe repair shop, and sometimes a tailor. Men

28. Anonymous, Qiyam-e Kargaran, p. 7. 
usually left during the day in search of work and returned "home" at night. Women and children stayed behind with the older people, who were no longer able to work. Women tended to look after the home rather than work elsewhere. Men mainly did odd jobs, and often they were unemployed in search of work. In 1962, about 8 per cent of the children, all boys, went to school; girls stayed at home. Some children, above the age of 7 , went to work in the glass factory. Those who worked during the day attended night school. Some children worked as peddlers, selling chewing gum. Those who worked at the factories made about is to 30 riyals per day.

Apart from the god-neshin [squatters], there were also karavansarayneshin. Their caravanserais consisted of many small spaces joined together around a court (hayat), which was covered with grass and animal dung. The rooms constructed around these spaces were made with mud; the roofing too was from makeshift material. The rooms had only one door and no windows, so it was pitch dark inside once the door was closed. The rooms were built at ground level and measured either three by four or three by two metres. They were rented for 20 to 30 tomans per month, and sometimes two families lived in the same room. Some of the caravanserais had a well, which was operated with a rope and bucket, but most did not have any. Those without a well therefore went to the public taps (shirfeshari [push taps]), and the better-off families bought water from peddlers. There were no facilities for sewage, and because the court was full of dirt people just dumped their sewage there. The Karavansaray-e Hajji Boluri, for example, housed about seventy families. It had no water tap - the nearest was 500 metres away and had only two hours of water per day. Consequently, there was a lot of fighting to get to the water every day. In this caravanserai, some rooms were rented to sheep-stomach cleaners (shirdan) and some to starch makers (neshastehgars). There were only five toilets for seventy families. The entire place was full of flies and covered with dirt and animal dung. Some families kept their horse or donkey in their room, just like they did in their village. These animals were part of the family, because families tried to make a living from them. These families had hardly any furniture, only a worn-out rug, a few utensils, and some worn-out coverlets. Each room usually contained five to twelve people. They had little income, and no permanent job. Like the rest of the brickkiln workers, they were villagers who could not make it in their village, and had come to the big city to find success.

Whereas in the godals some children at least went to school, here everybody had to work or hustle to supplement the family income. This also held for the women, who mostly worked outside the home. Only small children and those having no jobs hung around during the day. Some of the latter sometimes carried water around in the neighbourhood. The people living in the godals and caravanserais were all without skills, and 
consequently unemployment among them was high. Some worked in the construction industry and some at the brick kilns. Some had seasonal jobs, others found work at the factories. Because of the high rate of unemployment, these workers were happy to do anything. To avoid having to pay insurance premiums to the Ministry of Labour, the factories failed to report the correct number of people working for them. The workers, who were afraid to lose their jobs, were satisfied with their low wages, and gave thought neither to the future nor to their health.

Because the head of the family did not earn enough to make ends meet, the children had to work as well. Their wages were low, just i 5 to 30 riyals per day. An adult worker would make three to four times more than that. It was more profitable for the factory owners to hire children than adults. These owners usually did not report the names of these children to the authorities, because the Labour Law prohibited their employment. Therefore, it was also difficult to know how many children the factories actually employed. Women were mostly employed in wool carding, katira [gum tragacanth] cleaning, glass factories, brick kilns and the like, usually working in bad conditions - some of the factories had no drinking water for instance. They earned is to 30 riyals per day on the basis of their output. Women who breastfed their children took these with them to work and let them play in the dirt.

From a sanitation point of view the inhabitants of the godals and caravanserais lived in unhealthy conditions. They did not use much water, because they had to haul it from some distance and they also had to take away the sewage. This caused a lot of health problems, of course. At the same time, there were insufficient health facilities to serve these people. ${ }^{29}$

\section{LIVING CONDITIONS}

The kiln complex boasted some 100,000 inhabitants in 1957, of whom some 30,000 actually worked in the kilns. Every kiln had a row of Io to Is rooms, each 3 metres by 4 metres, which the kiln owner had built, in particular for the Khorasani workers, most of whom took their wives and children with them. The "Turkish"-speaking workers usually came alone. To reduce their living costs, these celibate qamir workers lived together; their monthly living costs were 50 tomans. ${ }^{3 \circ}$ The rooms were without windows or ventilation, but for a small opening above the door. In each of these "dwellings" lived three families. Usually ten to twelve child workers, who were away from their families, also occupied one of these rooms. Those workers employed in removing the bricks from the kilns, firing the

29. Anonymous, Sokhanraniha va Gozareshba dar Nakhostin Seminar Barrasi-ye Masa'el-e Ejtema'i-ye Shahr-e Tehran (Tehran, I343/1964), pp. 337-347.

30. Anonymous, Qiyam-e Kargaran, pp. 8, i 5. 
kilns, and stoking the fire lived right on top of the kiln. A small space in front of these rooms was used for washing and drying clothes, for cooking, and for chatting and relaxing after work. Bread was baked in small ovens that had been built there. Needless to say, dust was omnipresent.

In front of these rooms, 4 to 5 metres difference in elevation, the kiln operations began. All the rubbish was dumped in one corner, which at the same time doubled as a playground for the half-naked and bare-footed children. For every row of houses there were one or two water taps; one of these was 50 metres away and was used by the mud makers. The water was used by the workers for the kiln works as well as by their families. The latter used it to wash dishes and clothes, and to cook food, etc. One tap was installed close to the rooms because there was no sewage facility. The water formed stagnant, putrid pools I metre or $\mathrm{I} \frac{\mathrm{I}}{2}$ metres deep, which were dangerous for the children. For every row of rooms, there were one to four toilets, hardly sufficient given the number of people living there. Because of the proximity of the kilns the inside of the rooms was covered with a layer of dust. ${ }^{3 \mathrm{I}}$ The men and boys sometimes washed themselves at the kiln, but the women could not. They usually went to bed as dust-covered and dirty as they had been during the day. Most of the nearby bath-houses refused to admit the women, because they were too dirty; the few that let them in assigned them just a corner in some room, where they could wash. The "Turkish" workers had therefore built themselves a "bath-house" known as the Turkish bath-house, which consisted of two basins filled with water, which were heated with petroleum..$^{32}$

The workers spent most of their earnings on food, and their diet consisted mainly of bread, tea with sugar, fruit, and sometimes vegetables. Meat and other proteins were delicacies, and beyond what most workers could afford. Food prices were much higher than in nearby Tehran. ${ }^{33}$

Workers had little time to relax after their long working day, and having returned home after work they usually retired to bed after two hours. This was true for the permanent workers - the only ones who lived near the kiln during autumn and winter. They also unwittingly followed a rural lifestyle, working long hours, retiring and rising early. During the hours of relaxation prior to sleeping, they often sat together and discussed whatever took their fancy, while having tea or other stimulants. On their day off they split up. The young workers went into Tehran, others went to the cinema, or to the coffee houses, or visited a park or just sauntered in the

31. Anonymous, Gozareshi, pp. 7-8; Taheri, "Negahi”, p. Io9.

32. Anonymous, Gozareshi, p. I3; Anonymous, Qiyam-e Kargaran, p. 2.

33. For details on the health and nutritional conditions of slum dwellers in Tehran in I97 I see

Daneshgah-e Tehran (Sociology Department), Hashiyebneshinan-e Tehran; tagdhiyeh va bebdasht (Tehran, November 1973), unpublished report to the Plan Organization; Anonymous, Qiyam-e Kargaran, pp. 7-8. 
streets; some even went to the kiln to relax and chat. In spring and summer the seasonal migrant workers came to the kilns with their families. They also had little free time, and after work they hung around the kilns, made music, sang songs, and generally amused themselves. The Khorasani workers were observant Muslims, the Turkish workers less so. The Khorasanis made a pilgrimage to the Imamzadeh Davud, outside Tehran, once they had received their first wage. Despite their Muslim devotion, the Khorasani workers were generally addicted to nas, i.e. a mixture of quicklime and tobacco, a spoonful of which they put under their tongue, and then, after use, spat out. It was as dangerous as opium, which they also consumed. ${ }^{34}$ Some Khorasani workers invested their earnings in a motorcycle (an Izh, a Russian product), which made them mobile. They usually took it to their village to sell or to use, often with the intention of showing off their "wealth" to their peers. 35

\section{OFFICIAL GOVERNMENT ATTITUDE}

Until I94I, trade unions were prohibited in Iran, ${ }^{36}$ but after the abdication of Reza Shah and the invasion of Iran by the Allied Powers the new political and economic situation led, among other things, to the establishment of labour unions linked to political parties. The Tudeh [communist] Party was the most successful in organizing labour. Through strikes and political agitation, labourers were able to obtain wage increases and better working conditions in modern industry, and, finally, in 1949, the enactment of the first comprehensive form of labour legislation. To get a better hold on the various labour organizations, the Tudeh Party created the Central United Council of Trade Unions (CUCTU) in 1944. After World War II and the fall of the Azerbaijan Republic in late 1946, many Tudeh and labour activists were arrested. To counter the Tudeh Party's influence over labour, the government promoted the organization of noncommunist labour unions. In I 946 the Federation of Iranian Workers' Unions (ESKI B Ettehadiyeh-ye Sendika-ye Kargaran-e Iran) was set up. Ostensibly its function was to represent workers, but in fact its main task was to weaken the Tudeh's influence over labour. Its membership was drawn mainly from the railroads and government-owned factories. In I947 an ESKI leader broke away and formed a rival organization called the Central Federation of Trade Unions of Workers and Peasants of Iran (EMKA B Ettehadiyeh-ye Markazi-ye Kargaran). Its membership was drawn from the bazaars and from among craft workers, and its various unions were organized as personal followings of its leaders. There were

34. Anonymous, Qiyam-e Kargaran, pp. I5, I7-i 8; Taheri, "Negahi”, pp. IIO-III.

35. Anonymous, Qiyam-e Kargaran, pp. I6-17.

36. See for example Floor, "Labour Unions". 
other unions too, but these were the most important. After the assassination attempt on the Shah in 1949 the CUCTU was banned, and in I95 I ESKI, EMKA and EMKA Breakaway formed the Iranian Trade Union Organization. However, it languished because of lack of political support. After the Mossadeq government was ousted in 1953, the Shah tolerated only noncommunist labour organizations, though they were neither registered nor officially recognized. By 1957 the Mardom Party had set up a new labour federation, also called the Central Federation of Trade Unions (EMKA B Ettehadiyeh-ye Markazi-ye Kargaran). To be official, a labour union had to register with the Ministry of Labour, and only official labour unions could initiate a strike. ${ }^{37}$

The problem for labour was that working and living conditions were bad, wages very low, sanitation and safety usually lacking, and hope for betterment dim. This last element was also due to the fact that many unskilled workers expected a paternalistic attitude from management and considered themselves menials. The government was well aware of the problems of labour in general, and those of the brickworkers in particular. However, the government was totally focused on public security and was afraid that labour activity might lead to social unrest. Because of internal security concerns, the government tried to step in to dissuade (i.e. forbid) workers from actually going on strike. For these workers to strike meant, then, that things had really gotten out of hand and that some unwritten social code had been violated..$^{8}$

Foreign observers considered the Iranian labour force the most docile in the world. "The average worker asks only for fair treatment, for the opportunity to earn the minimum amount of money to feed, clothe and shelter himself and his family and to be paid the money he earns." Part of the problem lay with management, which was traditional in outlook and looked upon the workers as peasants. Even more hidebound in its outmoded social attitudes was the government. But it was to government that workers looked for a solution to their problems with management, rather than dealing directly with management itself. 39

Each factory having twenty or more workers had to have a factory council, on which there had to be a labour representative approved by the local Ministry of Labour official. Strikes were hardly ever started by a trade union, let alone by a group of workers; more often than not they were the work of one or two determined individuals, who, sparked by an incident, took action and were followed by their fellow workers. From the point of view of the Labour Law, very few strikes had been legal, since the

38. US Government, "Basic Survey", p. 94; UK Government, "Labour and Social Affairs I 956", p. 108 .

39. Ibid., pp. го9- I го. 
grievance procedure which the law set out was usually never followed. Also, many strikes were outlawed during periods of martial law. The usual procedure was for local officials from the Ministry of Labour either informally, or formally (as an ex-officio member of the factory council), to try to resolve the issue, with the support of the local authorities. Strikes were seldom settled by agreement between the workers and the factory's management. This was also the reason why most strikes did not last long, usually only a few hours, at the end of which the government representative announced his decision. It was also because the government feared public demonstrations, given its focus on maintaining public security after August 1953. Therefore, to avoid a threat to public order from run-away strikes, the government imposed a solution - one not always liked by either party, and in particular management..$^{\circ}$

Apart from the fact that registration of unions served to show the outside world that labour organizations were allowed in Iran, its real purpose was to serve the political objectives of its political patrons. Labour unions were not at all concerned with the rights of workers. Their adherents comprised retainers hoping for favours from and protection by their leader and his political patrons. The labour leaders used the union not so much to call a strike in order to bargain with factory management to promote workers' rights, but rather to negotiate better conditions for themselves from a government that feared labour and political unrest. In return, the government would pressure factory management to make certain concessions. The leaders of the labour movement were not elected by the workers; often, they were selected by factory management. The labour union served as a control mechanism for employers, and the labour organizer was more a spy for them than a person wishing to communicate and defend workers' interests. "The result is that labor groups are simply manipulated by management, by political party, or by government, or, when they strike, they are suppressed by force, since no other effective method has been provided." ${ }^{\mathrm{I}}$ This was also quite clear when the unorganized brickworkers, who had no idea about these matters, were organized into a labour union in 1958 , with official representatives whom they did not even know. They did, however, know certain thugs (chaqukesh), who also worked in the brick kilns and who served as spies for management. One such thug was Ahmad Boland, who also happened to be a union representative and who used strong-arm tactics to try to discourage workers from striking in $1977 . .^{42}$

40. Ibid., p. I I i; US Government, "Basic Survey", p. 93.

4I. Leonard Binder, Iran: Political Development in a Changing Society (Berkeley, CA [etc.], I962), p. I92.

42. Anonymous, Qiyam-e Kargaran, pp. 30-33. 


\section{THE STRIKING RECORD}

The first known strike by the workers of the brick kilns in southern Tehran occurred in 1953. Some 20,000 of them went on strike in July, around 5 weeks before the coup d'état of August 1953. For I I days the workers persisted in their strike. During that period, the strikers were allegedly helped by other factory workers as well as by small traders, who provided money and contributions in kind. ${ }^{43}$ Following the downfall of the Mossadeq government, martial law was established; once this had been lifted, the strict control the government exercised over any form of political and organizational activity precluded the occurrence of new strikes, despite the worsening employment situation for unskilled labour in Iran. However, when the situation deteriorated yet further even the docile brickworkers raised their voice.

The strike of July I957 was partly about the failure of the Ministry of Labour to apply Article ro of the Labour Law, relating to the minimum wage. In various parts of the country the minimum wage had to be fixed annually by a committee consisting of the mayor (farmandar), the head of the city council, the head of the local Bank-e Melli (the National Bank of Iran), or their representatives, a representative from the Ministry of Labour, two employer representatives and two employee representatives. Once the committee's proposal had been approved by the Supreme Council, it had to be implemented. This law had been approved in June I949 and promulgated by the Shah one month later. At that time the minimum wage had been fixed at 34 riyals. ${ }^{44}$ Since then, 8 years had passed and the minimum wage had not changed. The workers complained that their current wages did not cover the cost of living. At that time, foreign contractors working for the army had indicated that they would pay 250 riyals per day to unskilled labour and 500 riyals per day to a mason.

Reporters asked some of the people working in the mud ( $\mathrm{gel}$ ) how much they earned, to which they replied, " 3 tomans per day". Those engaged in khesht-mali (i.e. chuneb zadan in the workers' slang), a teenager, assisted by two 7- to- 8 year-old boys, made together 9 tomans per day. Workers also complained that the 1,000 bricks they made were sold for 70 to 90 tomans, while they received only 5 tomans. One of them said he, his wife,

43. Valiollah Moftakhari, "Lessons from the Iranian Workers' Struggles", WTUM 2 (I6-3 I January 1954), in Chaqueri, Condition, p. 74.

44. In principle the Labour Law of I 949 applied to "all workers, employers and workplaces irrespective of size". The law provided for an 8-hour working day and a 48 -hour working week, for payment of overtime ( 35 per cent), and for holidays and other benefits. It prohibited the employment of children below the age of I2. Article ro of the law required the Ministry of Labour periodically to fix and revise the minimum wage of unskilled labour, which should be adequate to cover the living expenses of a family of four. The law also included sections on unions, contracts, collective agreements, settlement of disputes, health and safety, and labour inspection. 
and his children made 3,000 moulds (khesht zad) and received only 9 tomans. His greatest fear was that it would rain, since this would ruin his bricks; the kiln owners would dock 50 per cent of workers' pay if the bricks were ruined due to rain. Workers also said that they were not on strike; they had simply stopped working until such time as they were paid the wages due to them.

The owners refused to give in to their demand for higher wages and told the workers to be back at work at 7 o'clock the next morning. At the start of 1957 the owners had promised a wage increase of 30 per cent. When the workers complained about the delay in payment, they were told to have patience. At the end of June, the owners of the Bahman and Tehran kilns agreed to pay the 30 per cent increase. The workers at the other kilns went to see their bosses, who once again told them to have patience and to come back later. But their patience had run out, and they resolved to strike. The strike started at the Jahan kiln and spread to other kilns, with the exception of those in Bahman and Tehran (since their owners had already accepted the workers' demand for 30 per cent higher wages). 45

Initially the owners, organized in the Ceramicists' Guild (Senf-e fakkhar), did not want to implement the pay rise. They gave two reasons. Firstly, because of the interference by EMKA (Markazi Kargaran) in the strike; the Brick-kiln Workers' Guild (Senf-e kargar-e kuzepaz) had only joined EMKA five months before. Secondly, because the moulders (qalebdars) were contract labour and worked only during the summer months. Their wages varied between 60 and I 20 riyals for a 16-hour working day. The rest of the year they were either idle due to the weather (rain, frost) or managed to make a little money as a qalebdar. The majority of workers were qalebdar, and therefore any increase would be applied to them. The owners finally gave in though, and the Ministry of Labour promised to hold talks on this issue with the Ceramicists Guild. ${ }^{46}$

Once the strike had been settled, the owners decided to increase wages from 70 to 75 riyals per I,000 raw bricks (khesht), with corresponding increases for other work. ${ }^{47}$ Although the strike was over, the underlying issues had not been dealt with. The payment of social security was still being discussed, and wages were falling in real terms due to high inflation. The situation in the brick-kiln fields therefore remained tense. It came as a major surprise then when workers in Tehran's brick industry were given a wage increase of about 40 per cent in the New Year (No Ruz) of I958. The labour contractors had granted the increase voluntarily - an extremely

45. Keyhan (6 Tir I 336/30 June 1957) and subsequent issues; Ettela'at (7 Tir 1336/r July 1957) and subsequent issues.

46. Ibid., (29 Dey I 336/i 8 January I958).

47. Keyban (6 Tir I336/30 June 1957) and subsequent issues; Ettela'at (7 Tir 1336/I July 1957) and subsequent issues. 
Table 2. Wage increases as a result of July 1957 strike

\begin{tabular}{lcc}
\hline In riyals per day & From & To \\
\hline Qermezchi (or ajordarbeyar) & 13.5 & 17.0 \\
Charkhkesh & 13.5 & 16.0 \\
Kurebsuz (or ateshkar) & 6.5 & 7.5 \\
Kurehchin & 5.5 & 6.5 \\
Moulders (qalebdars) & $70.0^{*}$ & $75.0^{*}$ \\
\hline
\end{tabular}

* Per I,000 bricks

unusual gesture. This was the second increase received by workers in this industry within the space of a year, although, given the rise in prices, this still did not leave them much better off. $4^{8}$

Despite the pay rise in 1958 , the employment and financial situation of the brickworkers had deteriorated, precipitating a one-week brickworkers' strike in Tehran, one of the most serious labour strikes the country had ever faced. The strike started on 6 June 1959, allegedly over the failure of employers to grant an increase in the minimum wage. ${ }^{49}$ The strike was said to have involved 30,000 workers, and a further 30,000 in ancillary occupations, notably truck drivers. In fact, even the government did not know the true number of workers involved because employers tried by various ways and means to avoid having to comply with the labour laws. Employers worked through labour contractors, for instance, who employed entire family units.

All I 70 -odd kilns stopped functioning. The strikers demanded a 35 per cent wage increase and an account of their wage deductions, which ostensibly were being deposited with the Workers' Social Insurance Organization, but which were more likely going into the pockets of the brick-kiln owners or the contractors responsible for bringing workers from rural areas to Tehran. Before the strike, the basic wage had been 95 riyals per $\mathrm{I}, 000$ bricks. Because of the rise in the cost of living, the brickkiln workers had seen their purchasing power deteriorate markedly. It was therefore feared that the strike might spread to other factories in Tehran, one reason why the Labour Department, supported by the police and the

48. US Government, "Labor Unrest in Iran, May 1958", in Chaqueri, Condition, p. I40, referring to EmbDes no. 57, I3 July 1957.

49. It was said that the work stoppage occurred because workers were angered by the failure of the negotiations presided over by the Labour Directorate of Tehran, which had started a few weeks earlier, to produce results. However, the British Embassy believed that the strike had been engineered by the employers, who sought to justify higher prices (and thus higher profits) by pointing out how much wages had increased. UK Government, FO 371/140891, "Workers' Strike", in Chaqueri, The Condition, p. I 50. 
Savak (Iran's secret intelligence organization), took steps to prevent further outbreaks. Although the strike was declared illegal, the Labour Department tried to mediate. On 7 June it was announced that a 20 per cent pay rise had been agreed and that work would resume on 8 June. However, the agreement had not been discussed with the workers, most of whom did not feel bound by it, and work was not actually resumed until I I June - and only after severe coercion by the police, the military, and the Savak. ${ }^{\circ}$ The strikers were worn down and forced to accept the kiln owners' offer of a 20 per cent rise, an offer supported by the Ministry of Labour as a reasonable basis for a settlement. In addition, the Ministry promised to look into the workers' other grievances, though this probably did not happen (at least no results were announced). ${ }^{5 \mathrm{I}}$

The Tebran Journal of is June 1959 wrote:

The strike of 60,000 brick kiln workers has come to an end or shall we say has been put to an end, but more to the rejoicing of kiln owners and middlemancontractors than to the satisfaction of workers. Besides the workers themselves, no intelligent observer, interested in the development of democracy in Iran, can be happy about the way the strike ended. In the process of the strike kiln workers were put in an undue position and were deprived of lawful bargaining rights. For this the Ministry of Labour is most to blame. Furthermore, why should the Ministry realize only now that for the last few years the employers have deducted the insurance premium from the workers' wages without paying it to the labour Social Security Office? Why should the Ministry realize only now that the employers should improve the working conditions in the brick kilns? If the Ministry has not been able to find out and end these injustices in so many years why does it declare the kiln workers' strike illegal?

The brick industry in Tehran is one of the largest industries in the country. Its 60,000 employees constitute 5 per cent of the capital's population. Hence, the kiln workers' plight is a grave social problem, which deserves constant, careful attention not only by the Ministry of Labour but also by the government as a whole and all civic-minded individuals. There are many vital steps to be taken. The middleman contractors, as the workers have repeatedly demanded, should be removed from the scene. They are not only superfluous, but harmful, as they get, after the recent increase, I 20 rials per I,000 bricks and pay the workers only 80 to 90 rials for the same number. [...] The Ministry of Labour can effectively assist the workers in their efforts to establish coops of their own. Last, but not

50. According to leftist sources, on 6 June 1959 the third and largest ever strike took place, involving 30,000 brick-kiln workers, who were demanding a 30 per cent wage increase. The security forces intervened using force, and 500 workers were killed and many more injured. Hundreds were put in prison. Anonymous, Jonbesh-e Kargari-ye Iran (Tehran, n.d.), pp. 90-91. US and British Embassy reports do not mention anybody being killed.

5I. UK Government, FO 371/140891, "Workers' Strike”, in Chaqueri, The Condition, p. I 50; US Government, "Annual Labor Report, 1959", in ibid., p. I 58 . The discussion on the payment of social security contributions for the brick-kiln workers had already started after the July 1957 strike and had continued into $195^{8}$, but it had not been resolved and things remained as they were, muddy and murky; Ettela'at (2 Bahman I336/2 I January I958), p. I 8. 
least, the Ministry should take urgent steps to force the kiln owners to improve the miserable, shameful working conditions. The one-room, underground "houses" in which the workers live - sometimes as many as twenty of them are not even worthy of Stone-Age cavemen. Of course all these improvements require great efforts and large amounts of money, but this is exactly what the Ministry of Labour is for. $5^{2}$

The British embassy commented: "The employers were clearly a set of rogues who had successfully evaded their responsibilities under the workers social insurance law by not paying over all social insurance contributions collected from their workers to the Workers' Social Insurance Organization." 53

In I96I, some 25,000 brick-kiln workers went on strike for the fourth time, demanding compliance with the Labour Law, and payment of their unpaid wages, workers' insurance, etc. ${ }^{54}$ In the political repression after the 1963 riots (which led to Khomeini being exiled), the government refused to tolerate any activity that challenged law and order, and no strikes took place - at least I have been unable to find any mention of them. The brickworkers did apparently go on strike again at the beginning of 1970 over a bonus payment, the so-called pul-e shirini, whose nonpayment had been a break-point for the workers. As a result, they received a promise of 2,000 tomans, but only if they stayed the entire season; if they left early, they would lose their right to it. 55 After this, there is no mention of strikes by brick-kiln workers in Tehran until I977. There was, however, a successful five-day strike of brick-kiln workers at Tabriz in April 1975; their demands were agreed to. ${ }^{56}$ The absence of strikes during the early I970s may paradoxically have been caused by the significant decline in GDP, with the construction industry being hardest hit. 57 However, pressure was rising, and industrial action, which was in the air, was finally taken when the rules on political activities were relaxed.

In July 1977 the Khatunabad workers went on strike again, for the fifth time (or possibly the sixth time, depending on whether there really had been a strike in the early 1970s). The movement began in a few kilns and then spread to the others, so that finally all the workers were involved. The immediate reason for the strike was the new price per $\mathrm{I}, 000$ bricks set by the government in July in consultation with the Kiln-owners Union

52. Cited in UK Government, FO 371/14089I, "Workers' Strike”, in Chaqueri, The Condition, pp. ISI-IS2.

53. Ibid., p. Is I.

54. Anonymous, Jonbesh-e Kargari-ye Iran, p. 95.

55. Anonymous, Qiyam-e Kargaran, p. I2 and note 2.

56. T. Jalil, Workers of Iran: Repression and the Fight for Democratic Trade Unions (London, I976), p. 56.

57. Amirahmadi, Revolution and Economic Transition, p. I9. 
(Ettehadiyeh kurehdaran) and the Kiln-workers Union (Sendika-ye kargaran-e kurehpazkhanehha). The workers were usually paid twice after their initial advance; the first time (pardakht-e avval) at the end of July, and the second time (pardakht-e dovvom) in September. In 1976 the pay for I,000 bricks had been 295 riyals, divided as follows: ostadkar 25 riyals; brick collector 25 riyals; brick-mould maker 95 riyals; and brickmould remover and clay maker each 75 riyals. Every Thursday, the kilnowners paid part of the wages in the form of an advance, which was taken out of the workers' pay. Given the development of wages and prices in the overheated market, the workers were expecting to get higher pay. Then one day it was announced on radio that from now on the wage of an assistant moulder (qalebkesh) would be 25 tomans per day; hitherto he had earned 7.5 tomans per I,000 bricks. The workers were very happy, assuming that they were to be paid 25 tomans per I,000 bricks - it had always been the custom to pay them per I,000 bricks rather than on a perday basis. In addition, there were already problems with regard to the payment of wage arrears. So when the employers failed to pay the wages, workers at the Amin kiln went on strike. Some contractors (ostadkar) joined the strike and encouraged the workers to stand their ground. These contractors were arrested, but released later on, after which they withdrew from the strike. The reason some of them had participated reflects their relationship to some of the strikers (family ties, friendship, etc.), but they also hoped to benefit from the higher wages that the workers were demanding.

That same evening, workers at the other kilns discussed whether to join the strike. They held a meeting during which the owners' agents (sar'amaleb) tried to dissuade them. Nevertheless, workers at three kilns decided to strike. On the fourth day, soldiers and gendarmes arrived at the kilns to force the workers to go back to work. The women tried to prevent the gendarmes from entering, and the men joined in the ensuing scuffle. Several workers were arrested and a few were injured, but the gendarmes left. The workers at the three kilns called on other Khorasanis to join the strike and demand that the price of $\mathrm{I}, 000$ bricks be raised to 60 to 70 tomans because of the rise in food prices. Intense discussions took place among the various groups of workers at each kiln. News and information was exchanged between the groups by workers on motorcycles. On Day 5 of the strike, the local head of the Ministry of Labour and a representative from the prime minister's office came to the Amin kiln and gave speeches. They exhorted the workers to return to work and pressured them with veiled threats. They promised to look into their complaints and told workers to return to work. They also invoked religious values, while mullahs too called on the workers to go back to work. The strikers rejected the government's offer, and complained to the government officials about their low pay, the arrears they were owed, and their other concerns. Some 
of the workers also claimed "we are not on strike; the works are idle because we have gone on a pilgrimage to Mashad".

The workers refused to budge. The government officials tried again. The workers insisted that "We are not on strike. Would you work if they had not paid you? We are three and a half months behind?" The government officials promised that the workers would be paid, if they returned to work. However, the workers were unmoved. Over the next few days, the strikers discussed how to put pressure on the workers at three others kilns which had continued to work to join the strike. A group of strikers decided to attack the kilns and destroy some equipment and raw bricks. The attackers then invited the other strikers to join them. The situation became chaotic and two arbabs (kiln owners) fled, afraid of being taken by the workers. After further demonstrations at the kiln, and after shouting slogans such as "Long Live the Shah!" (Javid Shab) and singing songs, the demonstrators went to the Amin kiln, entered it, and beat up some "Turkish" non-striking workers. However, the Khorasani and "Turkish" workers patched up their relations immediately. Once again the gendarmes intervened, using their guns as blunt instruments, and they surrounded the kilns. When the workers fought back, the gendarmes shot into the air and the ground and a few workers were wounded. Those workers who wavered were urged on by the more steadfast ones to continue the strike. Finally, the workers won and their wages were increased from 295 riyals for $\mathrm{I}, 000$ bricks to 500 riyals. The Khatunabad strike also had a positive impact on the wages of kiln workers at other locations. ${ }^{58}$

An unconfirmed report claims that brick-kiln workers in Tehran went on strike on is October 1978 demanding better working conditions. However, I have been unable to find any further information about this strike, nor even another source confirming its occurrence.59 In April i979, the Khatunabad workers went on strike again, for the sixth and last time. Encouraged by the success of the Islamic Revolution, on returning from having spent the winter in the rural areas they demanded higher wages because of the increased cost of living. They discussed their demands among themselves and then went to see the kiln owners. Because the kiln owners declined to take a decision, the workers went on strike in April 1979. It was, as usual, an uncoordinated affair because at first only a few kilns were affected. The workers involved went en masse to the other kilns to exhort them to join in. Not every worker wanted to join the strike, however, and there were differences of opinion among workers. Many of the strikers took up positions along the roadside, shouting their demands: “70 Tomans or Death - We Don't Want 50 Tomans!" When rebuked by angry passers-by for acting against the orders of Ayatollah Khomeini, who 
had declared all strikes illegal (haram) as being contrary to the interests of the Revolution, the strikers changed their tune and began shouting "By order of Khomeini, work has stopped; 70 tomans or death - we don't want so tomans!”

At that stage, members of the Revolutionary Committee (who had been gendarmes during the days of the Shah), accompanied by some contractors and kiln owners, came to ask the workers to end the strike and give the kiln owners time to formulate a response to their demands. The workers refused. One of the committee members then started to shoot in the air. A worker grabbed his arm and told him not to waste bullets. "You cannot scare us. We are already living in hell, so go ahead and shoot us." The workers decided to continue the strike, for prices had gone up: "We need the rise; you should be on our side, not that of the owners." Committee members began shooting in the air to break the strike; the same workers collected some of the shells and told the committee not to waste bullets, because they had been paid for out of public funds (bait al-mal). Then the situation deteriorated, with each party accusing the other of being counterrevolutionary. Seeing that they could not scare or convince the workers, the committee members then left.

Finally, the committee sent one of the olama to tell the workers that Khomeini did not want them to strike, and they promised to review their grievances. As a result of this appeal, the workers decided to leave the site but they did not return to work. After a week, the kiln owners gave in and agreed to the strikers' demands, namely:

(I) increase in wages from 50 to 70 tomans per I,000 bricks;

(2) increase in the wages of the winch operator (charkhkesh) to I 3 tomans;

(3) increase in the wages of those who stacked the bricks in the kiln (anbarzan) to I 3 tomans per I,000 bricks;

(4) increase in the wages of the brick removers (ajordarbeyar) to 7 tomans per ton;

(5) payment of 2 tomans per 1,000 bricks to the clay makers for collecting the broken bricks (saqatchiba-ye shekasteh);

(6) promise to give gloves, hats, shoes, and clothing to all workers;

(7) promise to construct houses, mosques, bath-houses, and toilets for workers;

(8) promise to provide insurance to workers; and

(9) establishment of a workers' council.

This brought an end to the strike. As a consequence, the kiln-owners raised the prices of bricks. Before the strike each brick had weighed about I I sir (I $\operatorname{sir}=75 \mathrm{gms}$ ), or $825 \mathrm{gms}$. After the strike, they changed the size of the brick, which now weighed about I, 800 gms. Before the strike, bricks were sold in batches of I,०00; thereafter bricks were sold by weight (per ton), and for every ton the owners received slightly more than i 50 tomans. 
While the workers were paid per I,000 bricks, a ton of bricks was now only 600 bricks. Since they carried them all day, the workers, in particular the children who took the bricks out of the mould and the women who collected the bricks, knew that the bricks had become heavier.

After the strike of April 1979 wages were raised from 50 to 70 tomans per I,०0० bricks. This was distributed among the workers as follows:

Mixer or gelsaz (usually one man)

Moulder or qalebdar (usually one man)

Assistant moulders or qalebkesh (usually two young boys) I 83 riyals Brick stackers or khesht jam'kon (usually two women) 7 7 riyals Contractor (ostadkar)

Total

I 83 riyals 193 riyals 83 riyals 70 riyals 700 riyals

The contractor's pay was equal to that of two brick collectors, although he did not actually work in the production team.

Despite the agreement, the kiln-owners reneged on some of their promises. For example, after the strike the owners were supposed to pay the mud makers 2 tomans per $\mathrm{I}, 000$ bricks produced in return for collecting the broken bricks and turning these into mud; this added up to about 50 tomans per week for the mud maker. However, some of the contractors did not pay. Nor were the protective clothing and hats given either. Some of the brick-mould makers received gloves, some of the brickmould removers got shoes, or rather givehs; but the others got nothing. Also, those work gangs that could not keep up with productivity were told that they would be laid off if the situation did not improve, and some were indeed dismissed during the summer.

Until I980, the contractors were the workers' representatives. But the workers did not want them anymore and demanded that their representatives be illiterate workers like themselves, who knew from their experience of having worked in the kilns what their life was like. Some workers did not even know who their representative was. Finally, in the middle of August 1979, some of the Khatunabad workers elected their representative for the workers' council; others did not participate, because they did not trust the procedure, nor the fact that a representative from the Ministry of Labour was present. ${ }^{60}$

\section{AFTER I 980}

As far as I know, there were no more strikes at Khatunabad after I979, despite the fact that between 1976 and 1986 employment in the construction industry fell 10.6 per cent more than in any other industrial sector. This was due partly to the restructuring of the industry, partly to

60. Anonymous, Gozareshi, pp. 17-22. 
the war with Iraq, and partly to the suppression of labour protest. ${ }^{61}$ On 7 April I98I, the Supreme Court (Dadsetan-e koll) issued a decree forbidding support for strikes. ${ }^{62}$ The attitude of the Islamic Republic of Iran (IRI) even gave rise to complaints from the Islamic Council, because critical workers were sacked or harassed just as they had been before 1979 . Often, those who protested were branded as leftists, if not counterrevolutionaries. Nevertheless, the IRI changed the structure of wages towards a more equitable income distribution, though the outbreak of war with Iraq made any form of criticism suspect, and thus impossible.

The IRI's ambivalence towards labour is underlined by the continued absence of a new labour law, and the fact that the old I959 law is still in force. Its application does not seem to have been any different from the period before 1979. Unskilled labour received an average annual pay increase of 13 per cent in I980, while the wages of skilled labour dropped by 10 to I 2 per cent (and those of government workers by as much as 20 per cent). It was only in 1985 that, for the first time, the minimum wage was officially raised, and even then only by i I per cent. Workers' councils had insisted that the annual mandated review should fix the rate based on at least the rate of annual inflation. The official inflation rate of $2 \mathrm{I}$ per cent (1979-I984) eroded the real value of most wages. This was partly offset by coupons for food as well as for other necessities. However, unofficial figures, as well as the existence of an active black market, indicate an inflation rate of 30 per cent during 1979-1984. The structural problems of the labour force (illiteracy, poor housing, lack of skills, malnutrition) do not seem to have been dealt with. Granted, Iran was at war and thus many problems could not be given the attention they needed. But even today there has been no fundamental change in the government's attitude to labour. Like the Pahlavi regime, the IRI does not seem to favour free speech or the freedom to organize in an open society, where people can make their own choices rather than having choices made for them.

Finally, despite their illiteracy, their lack of information, their ethnic diversity, their village-cultural baggage, and their lack of representation, the brick-kiln workers were willing and, at times, able to demand and defend their rights. At the same time, however, these same characteristics impeded the development of their indignation into a sustained and targeted militancy that would have tried to challenge and transform the socioeconomic and political context in which they had to operate. They were able to resist attempts by employers, who played on ethnic differences, to allow this to become a divisive force. They were also able to resist the repression of their legitimate rights guaranteed by the Labour Law. But they were unable to overcome their traditional values of respect for their 
elders and for authority. The majority of brick-kiln workers wanted to be represented by people like themselves, who had paid their dues with hard work; they were dismissive of young urbanites with radical ideas. But both before and after 1979, they were (and still are) unwilling to question the legitimacy of political leadership, or the negative social status ascribed to them. They wanted only for employers and the government to do what was right, and to guarantee them employment sufficient to allow them to take care of their families. To an extent, the IRI seems to have been able to provide this assurance of job security and respect for some labour rights. It has not, however, allowed workers to pursue their own socio-economic and political objectives and interests. 